\title{
ANATOMIA DE ÁPICES RADICULARES DE FEIJÃO cV. CARIOCA SUBMETIDOS A NÍVEIS DE BORO EM SOLUÇÃO NUTRITIVA'
}

\author{
Marina Aparecida Moraes-Dallaqua²*; Celia Massa Beltrati ${ }^{3}$; João Domingos Rodrigues² \\ ${ }_{3}^{2}$ Depto. de Botânica, IB/UNESP - Campus de Botucatu, C.P. 510 - CEP: 18618-000 - Botucatu, SP. \\ ${ }^{3}$ Depto. de Botânica, IB/UNESP - Campus de Rio Claro, C.P. 199 - CEP: 13506-900 - Rio Claro, SP. \\ *Autor correspondente <marina@botunet.com.br>
}

RESUMO: Foram estudadas as alterações anatômicas em ápices radiculares do feijoeiro (Phaseolus vulgaris L. cv. Carioca), quando submetidos a diferentes níveis de boro em solução nutritiva. Através de um experimento inteiramente casualizado, foram realizados três tratamentos como se segue: $T_{1} 0,50 \mathrm{mg} \mathrm{L}^{-1}$ de boro (testemunha); $\mathrm{T}_{2} 0,25 \mathrm{mg} \mathrm{L}^{-1}$ de boro (nível intermediário); $\mathrm{T}_{0}$ omisso em boro; sendo feitas amostragens em três estágios sucessivos de desenvolvimento da planta, no decorrer de seu ciclo. As alterações foram avaliadas efetuandose secções longitudinais de ápices radiculares, sendo analisados comparativamente por meio de estudo citohistológico com o emprego de microscópio de luz. Considerando como testemunha as plantas submetidas ao nível de $0,50 \mathrm{mg} \mathrm{L}^{-1}$ de boro na solução nutritiva, pôde-se verificar que a omissão desse micronutriente, na solução nutritiva, provocou inibição da divisão e alongamento celular, hipertrofia de células, desorganização de elementos vasculares em raiz, impedindo que a planta completasse seu ciclo, morrendo ao redor do 550. dia após o transplante. O nível de $0,25 \mathrm{mg} \mathrm{L}^{-1}$ de boro, na solução nutritiva, embora tenha provocado desorganização no ápice radicular, não impediu o desenvolvimento da planta.

Palavras-chave: Phaseolus vulgaris, anatomia, nutrição mineral, raiz

\section{ANATOMY OF THE ROOT APEX OF THE COMMON BEAN RECEIVING BORON IN NUTRIENT SOLUTION}

\begin{abstract}
The aim of this work was to study morphological changes in the growth of Phaseolus vulgaris $\mathrm{L}$. cv. Carioca when submitted to different levels of boron in a nutrient solution. Three treatments were applied in four completely randomized replications: $\mathrm{T}_{1} 0.50 \mathrm{mg} \mathrm{L}^{-1}$ of boron (control); $\mathrm{T}_{2} 0.25 \mathrm{mg} \mathrm{L}^{-1}$ of boron (intermediate level); $T_{0}$ without boron. Samples were taken at three growth stages. Changes were evaluated through sections of root tips. Cellular division was inhibited when beans were grown in a solution without $B$. There was hypertrophy of the vascular cells and the plants died 55 days after emergence. At $0.25 \mathrm{mg} \mathrm{L}^{-1} \mathrm{~B}$, there was a disorganization of root tip cells which was not severe enough to impair plant growth.

Key words: Phaseolus vulgaris, anatomy, mineral nutrition, root
\end{abstract}

\section{INTRODUÇÃO}

O feijão é um dos alimentos básicos de vários povos, principalmente do brasileiro, constituindo a sua principal fonte de proteína vegetal (Ambrosano et al., 1996). Segundo Pompeu (1987), seu teor proteíco pode chegar a $33 \%$ com valor energético de 341 cal $100 \mathrm{~g}^{-1}$.

$O$ desenvolvimento e o rendimento do feijoeiro (Phaseolus vulgaris L.) são seriamente afetados, quando ocorre deficiência de algum elemento essencial, sendo a deficiência de boro bastante característica (Malavolta et al., 1980a).

As respostas consideradas por vários autores como resultantes da deficiência de boro, em diversas plantas estudadas, incluem inibição do crescimento radicular, ausência ou anormalidade na diferenciação vascular, principalmente em relação ao floema, e necrose do ápice radicular (Mcllrath \& Palser, 1956; Marschner, 1986; Gupta, 1993; Moraes-Dallaqua et al., 1998). No entanto, existem controvérsias entre os pesquisadores, ao considerarem qual o efeito primário do boro: biossíntese de lignina e diferenciação do xilema (Lewis, 1980), estabilização da membrana plasmática (Pilbeam \& Kirkby, 1983) ou alteração em reações enzimáticas (Lovatt, 1985).

Embora sejam muitos os trabalhos, relatando as respostas de plantas às variações no suprimento de macro e micronutrientes, comparativamente, são poucos os que tratam das mudanças que nelas ocorrem a nível anatômico. Assim sendo, este trabalho teve por objetivo estudar as alterações anatômicas em ápices radiculares de feijoeiro quando submetidos a três diferentes níveis de boro em solução nutritiva.

\section{MATERIAL E MÉTODOS}

No presente trabalho, foram utilizadas sementes de feijoeiro (Phaseolus vulgaris L. cv. Carioca) procedentes da Estação Experimental de Votuporanga, do Instituto Agronômico de Campinas - SP. Segundo Almeida et al. (1971), esse cultivar apresenta crescimento indeterminado e ciclo vegetativo ao redor de 90 dias.

\footnotetext{
${ }^{1}$ Parte da Tese de Doutorado da primeira autora apresentada ao IB/UNESP - Rio Claro, SP.
} 
Para obtenção das plantas, as sementes foram desinfectadas segundo técnica adotada por Malavolta et al. (1980b). Foram, então, colocadas para germinar em bandejas de polietileno, tendo como substrato algodão e papel de filtro, devidamente esterilizados e umedecidos com água desmineralizada.

As sementes germinadas foram transferidas para outras bandejas de polietileno, contendo quartzo moído, umedecido diariamente com água desmineralizada. Assim que as plântulas começaram a perder os cotilédones, foram transplantadas para vasos contendo solução nutritiva $\mathrm{n}^{\circ}$ 2, preconizada por Hoagland \& Arnon (1950). A partir dessa solução, contendo $0,50 \mathrm{mg} \mathrm{L}^{-1}$ de boro, foram estabelecidos os tratamentos, com três diferentes níveis de boro, que foram os seguintes: $T_{0,50}$ (solução controle), $T_{0,25}$ (solução com $0,25 \mathrm{mg} \mathrm{L}^{-1}$ ) e $\mathrm{T}_{0}$ (solução omissa).

$\mathrm{O} \mathrm{pH}$ das soluções nutritivas foi mantido em torno de 6,0, sendo realizado seu controle por meio de leituras periódicas e quando necessário, ajustado com $\mathrm{KOH} 0,1 \mathrm{M}$. Foi realizada a renovação das soluções nutritivas por três vezes, bem como o controle diário do volume das mesmas. No controle de pragas e doenças, as plantas foram pulverizadas, por duas vezes, com Phosdrin CE-2 (2,5 $\left.\mathrm{ml} \mathrm{L}^{-1}\right)$ e Dithane $\mathrm{M}-45\left(2 \mathrm{~g} \mathrm{~L}^{-1}\right)$.

Foram realizadas três amostragens, durante 0 ciclo do vegetal, distribuídas como se segue: COLETA I20 dias após o transplante, com a planta em início de crescimento vegetativo; COLETA II- 40 dias após o transplante, com a planta em início de florescimento; COLETA III- 60 dias após o transplante, com a planta em final de ciclo.

Para o estudo anatômico, os ápices das raízes amostradas foram fixados em FAA 50 (Johansen, 1940) por 24 horas e estocados em álcool 70\%. Para a confecção das lâminas permanentes, o material vegetal foi desidratado em série etílica ascendente, infiltrado e incluído em parafina (Sass, 1951).

As secções longitudinais do ápice radicular, com espessura de $8 \mathrm{~mm}$, foram obtidas em micrótomo rotativo, e coladas à lâmina com adesivo de Mayer (Johansen, 1940). A seguir, foram desparafinizadas em xilol, coradas com Safranina - "Fast Green - FCF" e montadas em resina sintética "Permount" (Johansen, 1940). As ilustrações foram feitas através de fotomicrografias obtidas em fotomicroscópio Carl Zeiss modelo Axioskop.

\section{RESULTADOS}

\section{COLETA I - Início de crescimento}

O ápice radicular das plantas controle (Figura 1) mostra uma área central composta de células, sem diferenciação nítida, que constitui o conjunto de células iniciais. Envolvendo o meristema sub-apical, a coifa apresenta células centrais que dividem-se num plano transversal, formando uma columela (Figura 3). Logo acima do meristema sub-apical, inicia-se a diferenciação do estelo, com células centrais se alongando, tornandose vacuolizadas (Figura 1). A $330 \mu \mathrm{m}$ do ápice da coifa (Figura 2) observam-se as células do meristema fundamental que se alongam radialmente dando origem ao córtex; a região do periciclo e da endoderme é constituída por células pequenas, cujo citoplasma é denso e núcleo evidente, e que se dividem uma ou duas vezes (Figura 2).

Nas raízes das plantas submetidas à $0,25 \mathrm{mg} \mathrm{L}^{-1}$ de boro, observa-se desorganização dos tecidos da extremidade distal do ápice, não sendo possível a distinção entre meristema sub-apical e coifa, pois as células são de vários formatos e tamanhos, sendo que as da extremidade encontram-se em degeneração (Figuras 4 e 7). A $2500 \mu \mathrm{m}$ da extremidade do ápice, aparecem primórdios de raízes laterais (Figuras 5 e 6 ), ao lado de elementos traqueais já diferenciados (Figura 6), sendo que as células do primórdio de raiz lateral, mostram nucléolos evidentes (Figura 5).

Nas plantas submetidas à omissão de boro, a estrutura dos ápices radiculares (Figuras 8 e 10) mostra um conjunto de células, de vários formatos e tamanhos, cujos núcleos não são evidenciados, sendo que algumas dessas células encontram-se rompidas e colapsadas. Algumas células centrais, no ápice, encontram-se

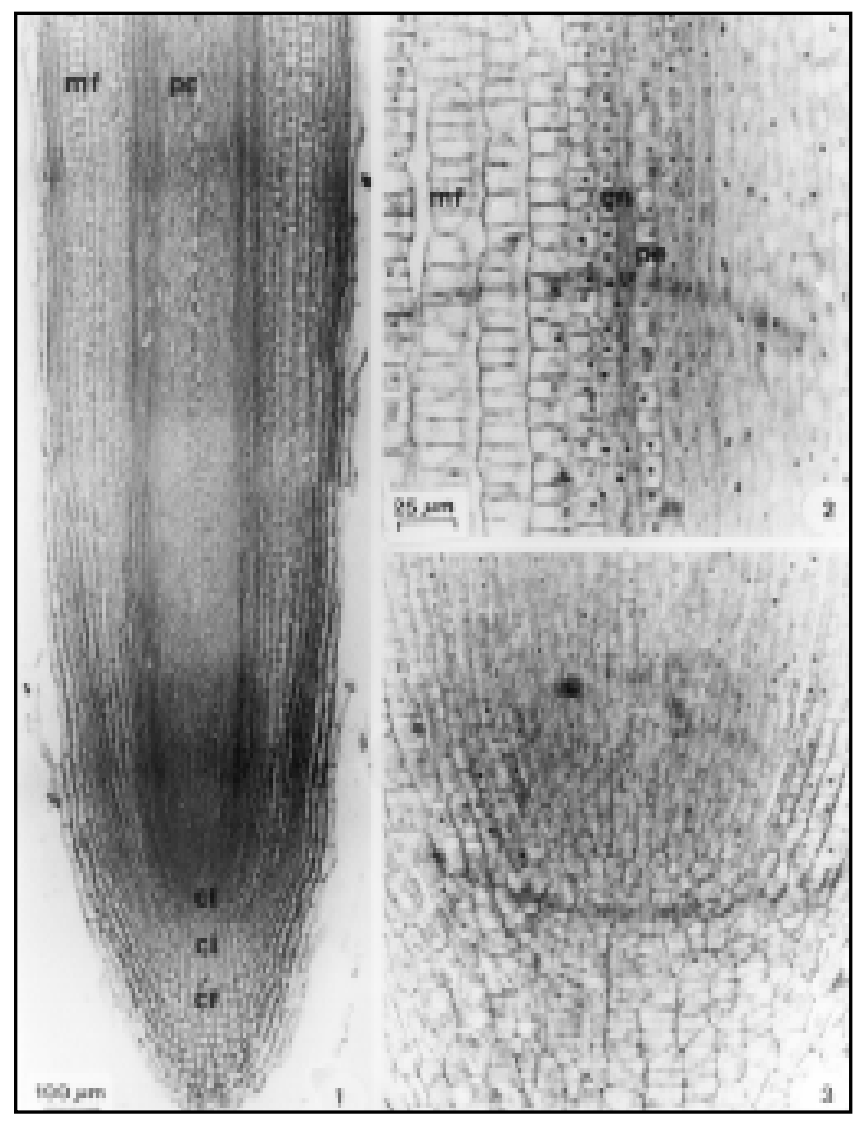

Figuras 1-3 - Secções longitudinais medianas de ápices radiculares. Coleta I-T0,50. 1: Aspecto geral. 2: Pormenor das células do meristema fundamental. 3: Pormenor da região do meristema sub-apical e da coifa. (cf-coifa; ci-células iniciais; cl-columela; en-endoderme; mf-meristema fundamental; pe-periciclo; pc-procâmbio). 
alongadas, tendo paredes de coloração marron, e contendo material denso (Figura 10), que se mostra corado de vermelho. Na região do periciclo, aparecem primórdios de raízes laterais, cujas células estão se dividindo em vários planos (Figura 9). Alguns dos primórdios radiculares observados não apresentavam organização nítida.

\section{COLETA II - Início de florescimento}

Os ápices radiculares das plantas testemunha apresentam a mesma organização descrita anteriormente, para as plantas da Coleta I.

As raízes das plantas amostradas, submetidas a $0,25 \mathrm{mg} \mathrm{L}^{-1}$ de boro na solução nutritiva, apresentam ápices parcialmente organizados, constituidos por células intactas, longitudinalmente alongadas, de paredes delgadas, citoplasma pouco denso e núcleos pouco evidentes (Figura 11). Na coifa, a columela não se diferencia, havendo células hipertrofiadas no centro, e na

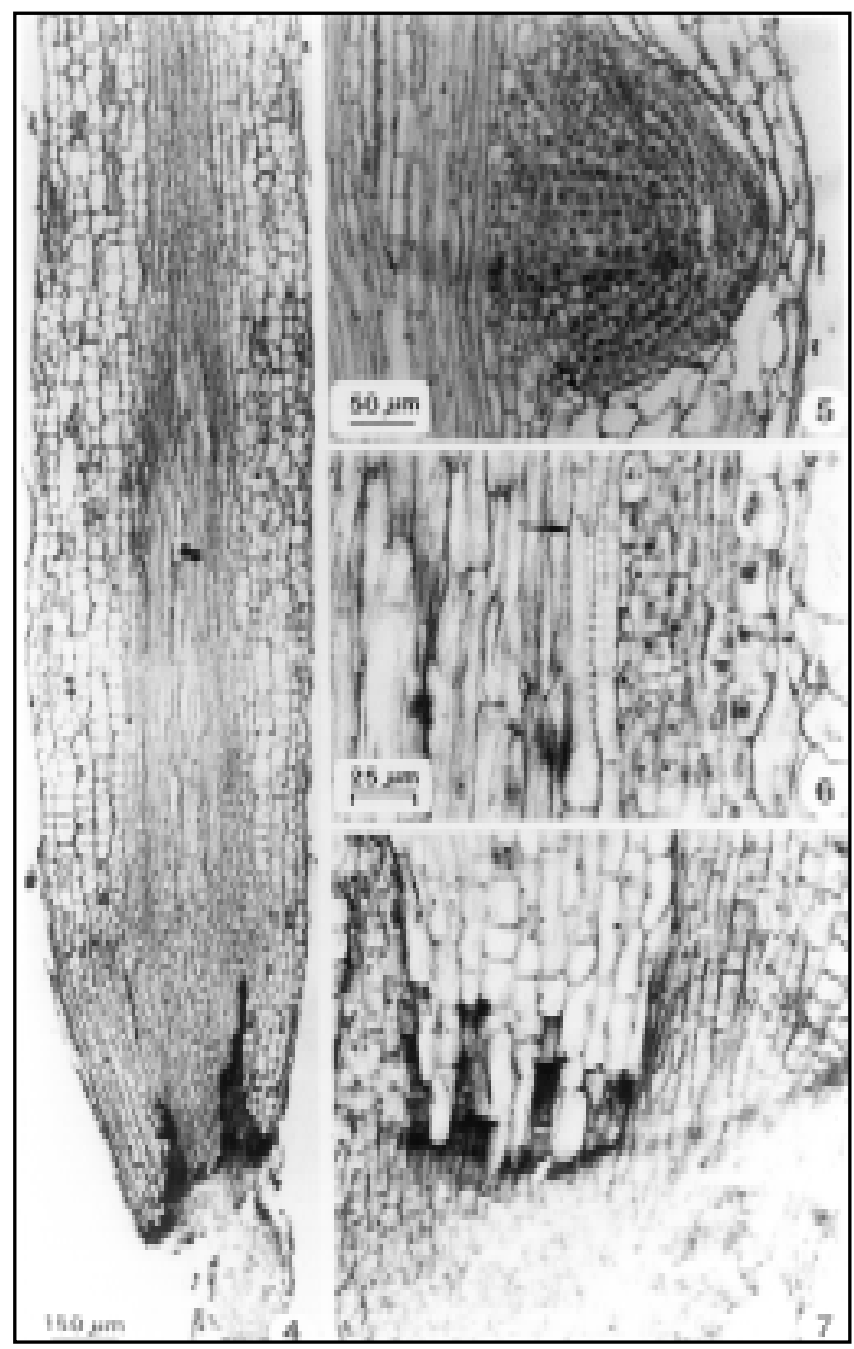

Figuras 4-7 - Secções longitudinais medianas de ápices radiculares. Coleta I-T0,25. 4: Aspecto geral. 5: Por menor do primórdio de raiz lateral. 6: Pormenor de elementos traqueais, já diferenciados, a 2.500 $\mu \mathrm{m}$ do ápice da coifa (seta). 7: Pormenor da extremidade do ápice, mostrando a região necrosada. periferia, células colapsadas com as paredes fortemente coradas (Figura 13). A $231 \mu \mathrm{m}$ do ápice da coifa, observam-se células já diferenciadas formando o córtex, enquanto no centro, as células se mostram alongadas, e a $1254 \mu \mathrm{m}$, no procâmbio, já aparecem elementos traqueais diferenciados (Figura 12), que logo acima, encontram-se rompidos.

O ápice radicular de plantas submetidas à omissão de boro (Figura 14) constitui-se de células mortas, com paredes colapsadas, rompidas e coradas de vermelho, sendo que a região correspondente à coifa apresenta células de formato irregular. A $215 \mu \mathrm{m}$ da extremidade do ápice, encontram-se células alongadas e estreitas, com paredes espessas e conteúdo fortemente corado (Figura 17). Tanto no córtex como no cilindro vascular, devido ao rompimento das células, observam-se numerosos núcleos livres (Figura 16). A $1100 \mu \mathrm{m}$ do ápice, as células centrais mostram-se intactas, surgindo vários primórdios de raízes laterais, constituídos por células de formatos variados (Figura 15).

\section{COLETA III - Amadurecimento dos frutos}

O ápice radicular das plantas controle mostra tecidos com nítida organização. Nesta coleta, as plantas submetidas a $0,25 \mathrm{mg} \mathrm{L}^{-1}$ de boro, na solução nutritiva,

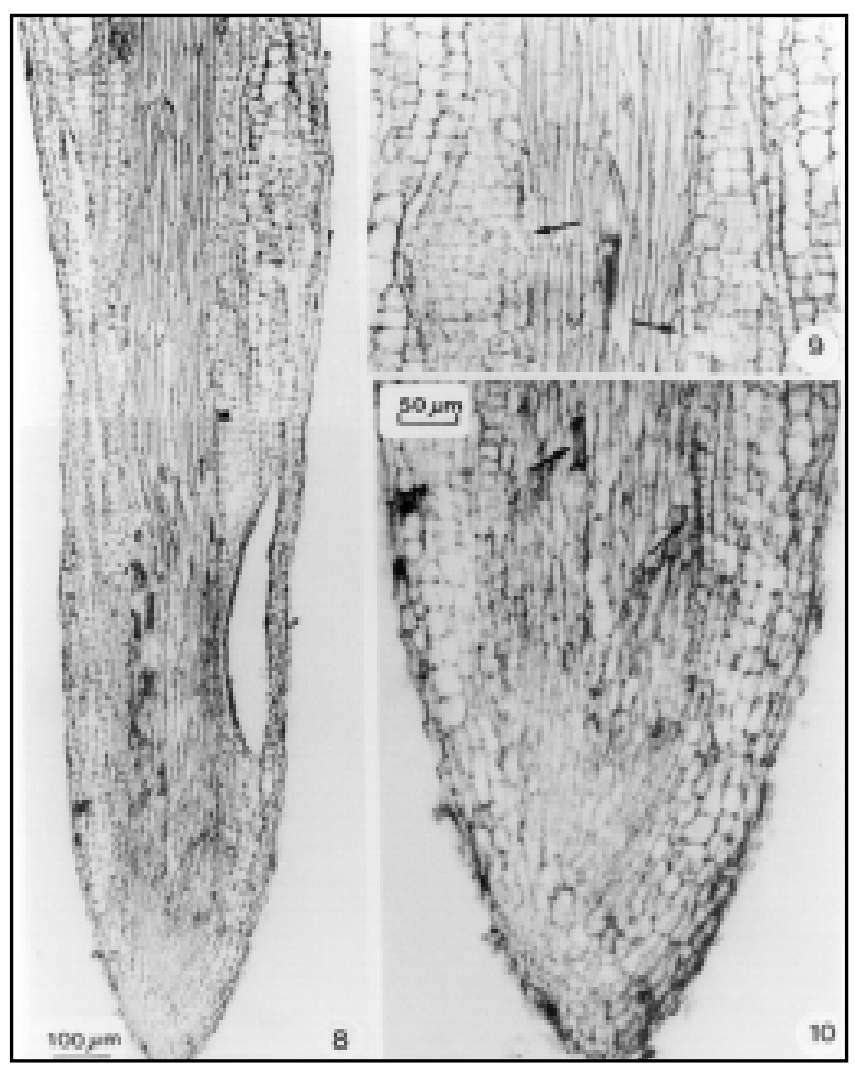

Figuras 8-10 - Secções longitudinais medianas de ápices radiculares. Coleta I-T0. 8: Aspecto geral. 9: Por menor da figura anterior, com as setas indicando primórdios de raízes laterais. 10: Pormenor da extremidade do ápice, mostrando células com conteúdo marrom (setas). 


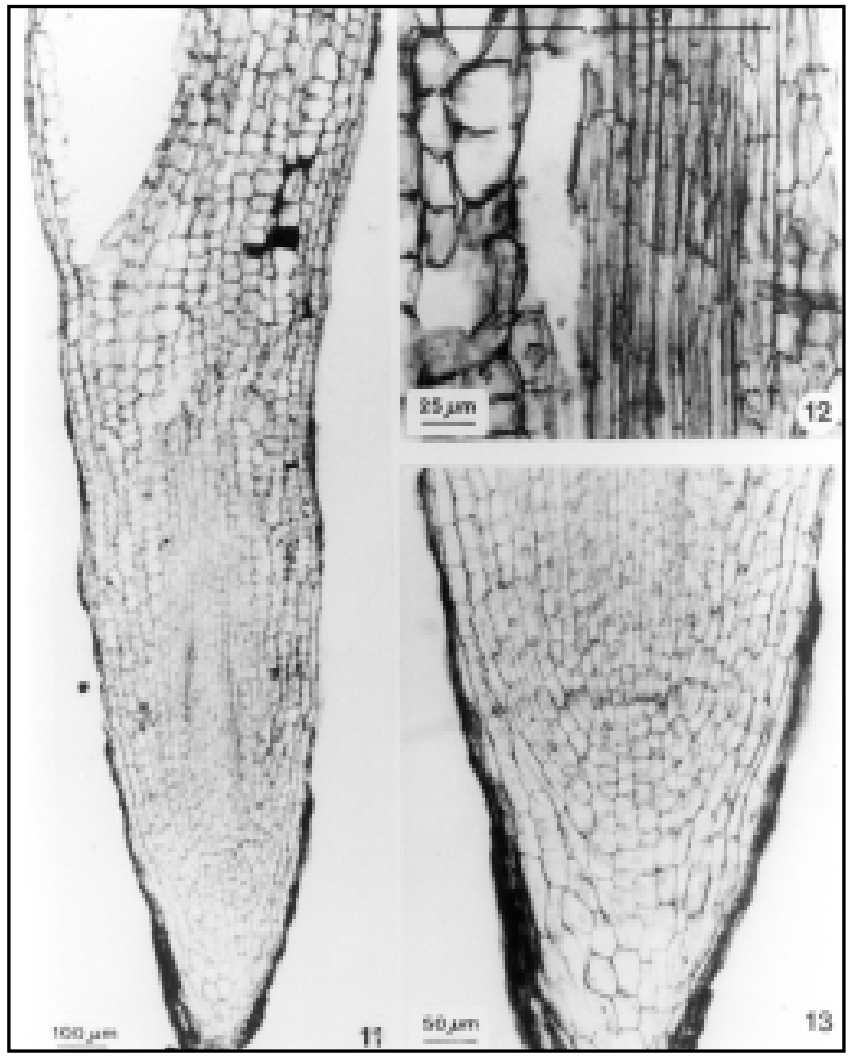

Figuras 11-13 - Secções longitudinais medianas de ápices radiculares. Coleta II-T0,25. 11: Aspecto geral. 12: Pormenor de células corticais e de elementos traqueais diferenciados. 13: Pormenor da extremidade do ápice. (c-córtex; cv.-cilindro vascular).

apresentam ápices de raízes laterais parcialmente organizados (Figura 18). A $231 \mu \mathrm{m}$ da extremidade distal do ápice, as células do córtex apresentam-se hipertrofiadas (Figura 19), algumas estando colapsadas com conteúdo fortemente corado. Embora o ápice esteja aparentemente bem organizado, a $1453 \mu \mathrm{m}$ dele, observase um primórdio de raiz lateral, cortado transversalmente (Figura 20).

Por ocasião desta amostragem, as plantas submetidas à omissão de boro na solução nutritiva já se encontravam mortas.

\section{DISCUSSÃo}

$\mathrm{Na}$ estrutura do ápice radicular de Phaseolus vulgaris L. cv. Carioca, não é possível distinguir grupos específicos de células iniciais. Segundo Esau (1965), meristemas apicais com células iniciais sem uma diferenciação nítida para as regiões da raiz, têm sido descritos nas dicotiledôneas e especificamente para as leguminosas.

No meristema sub-apical da raiz das plantas de feijão, em estudo, pôde-se constatar que as células iniciais do estelo estão situadas na região central do ápice, enquanto que logo abaixo, encontram-se as células iniciais

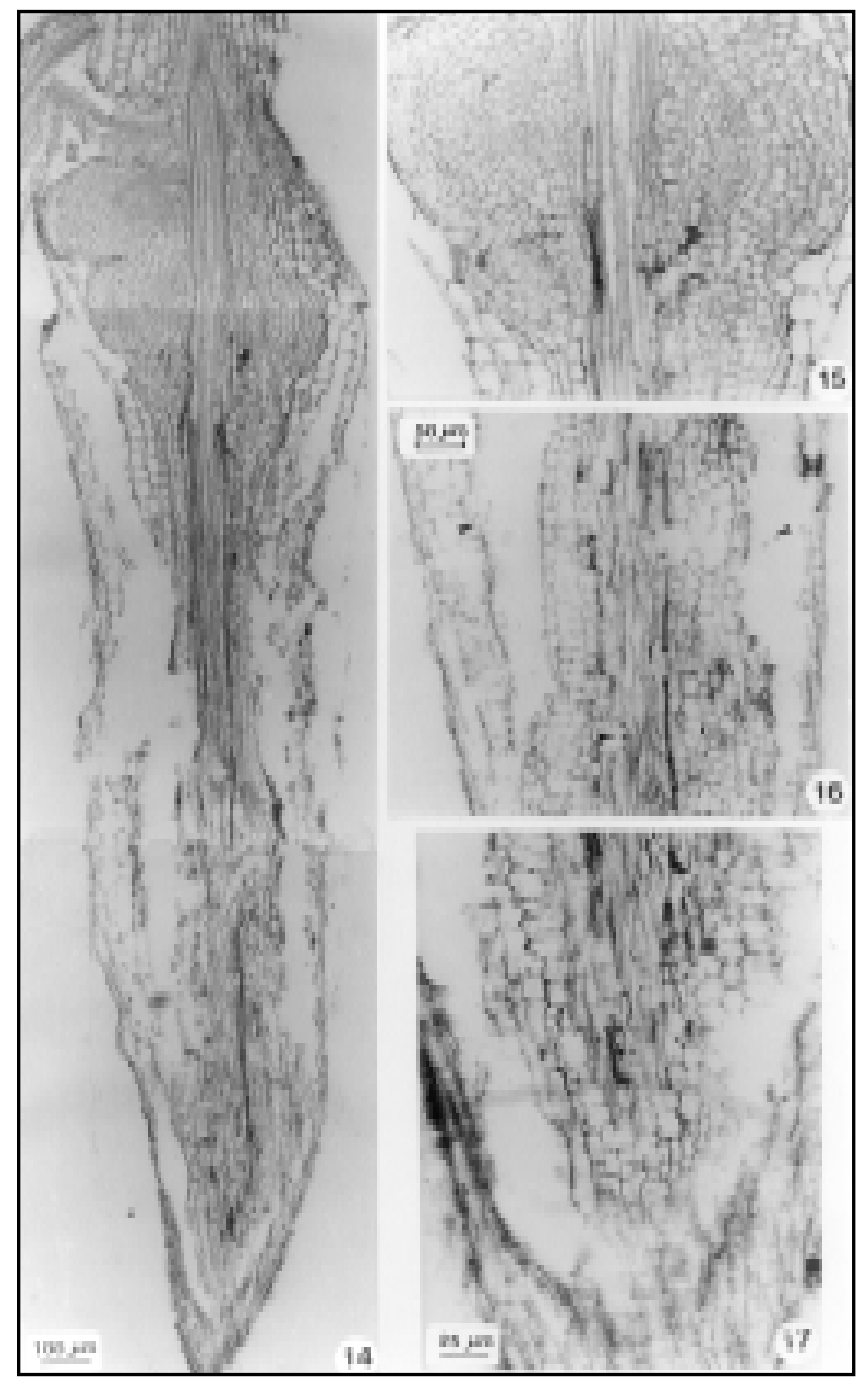

Figuras 14-17 - Secções longitudinais medianas de ápices radiculares. Coleta II-T0. 14: Aspecto geral. 15: Pormenor da região em que aparecem os numerosos primórdios de raízes laterais. 16: Pormenor da região do córtex e cilindro vascular, mos trando numerosos núcleos livres (setas). 17: Pormenor da extremidade do ápice, mostrando células alongadas com conteúdo fortemente corado.

comuns, distribuídas em camadas, orientadas perpendicularmente ao eixo do ápice, que formarão o córtex e a epiderme. Esta organização é semelhante à ilustrada por Silva (1989), para o ápice de Phaseolus vulgaris cv. "Bush Blue Lake 290", sendo este tipo de organização denominado "aberto" (Fahn, 1982). Este padrão é reportado também para Pisum sativum (Popham, 1955) e Glycine max (L.) Merrill (Miksche, 1961).

Através da análise histológica das secções longitudinais das raízes, submetidas ao T0,25, verificouse, já na ocasião da Coleta I, a ocorrência de desorganização e necrose do ápice radicular, o aparecimento de primórdios radiculares muito próximo à região meristemática, bem com a maturação precoce de elementos traqueais em relação às plantas controle. 


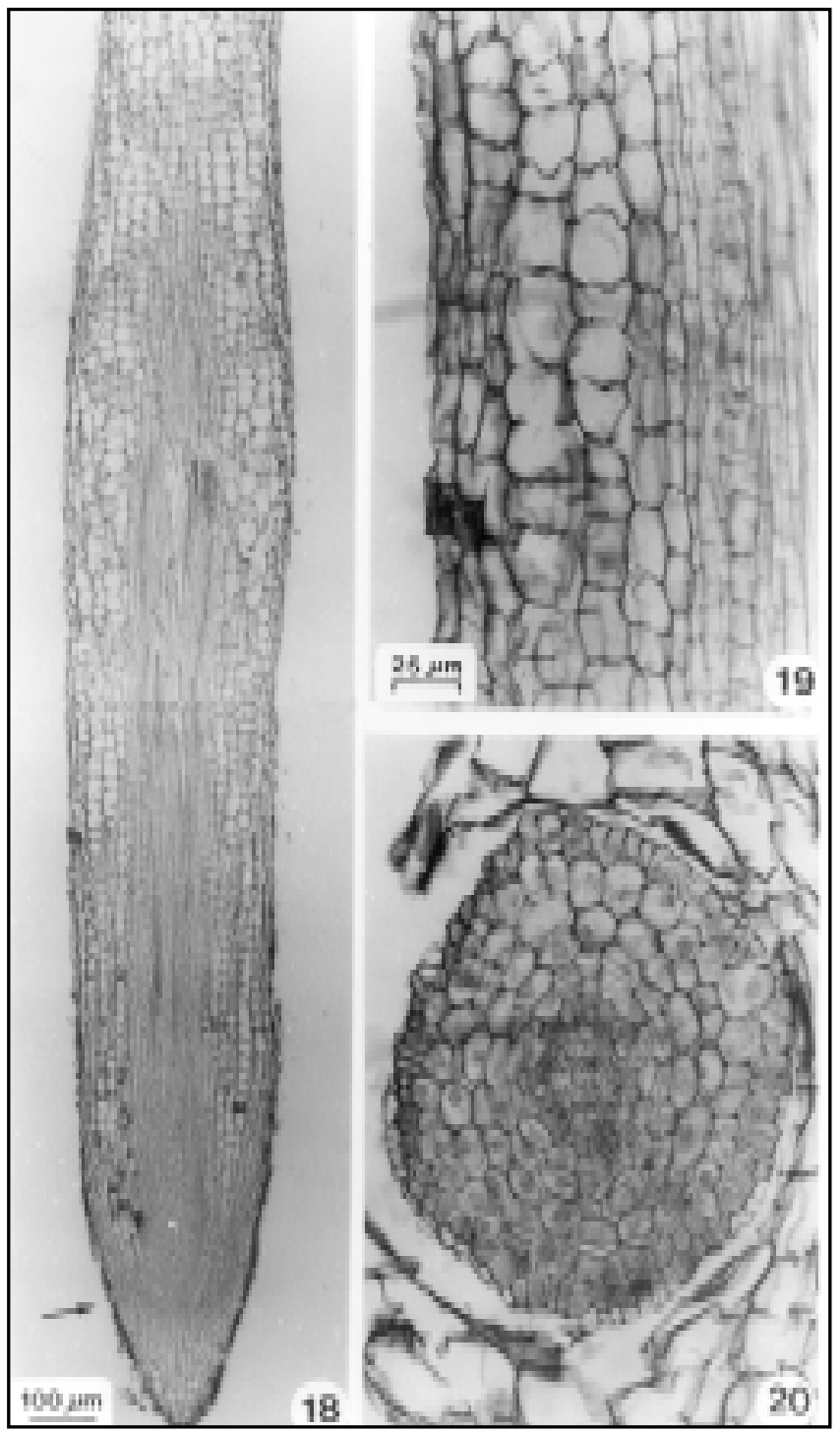

Figuras 18-20 - Secções longitudinais medianas de ápices radiculares. Coleta III-T0,25. 18: Aspecto geral, mostrando a região do meristema apical parcialmente organizada (seta). 19: Pormenor da região do córtex, mostrando células hipertrofiadas. 20: Pormenor de um primórdio radicular, visto em secção transversal a $1453 \mu \mathrm{m}$ do ápice da coifa.

Van De Venter \& Currier (1977) estudando plantas de feijão (Phaseolus vulgaris L. var Red Kidney), consideraram $0,25 \mathrm{mg} \mathrm{L}^{-1}$ de boro, na solução nutritiva, como o nível ótimo para o desenvolvimento das mesmas. No entanto, em vista da ocorrência de alterações estruturais observadas no presente trabalho, parece mais apropriado considerar que o nível de $0,25 \mathrm{mg} \mathrm{L}^{-1}$ de boro, na solução nutritiva, não foi suficiente para manter o desenvolvimento adequado das raízes, induzindo o aparecimento de sintomas de deficiência desse micronutriente.

Segundo Lovatt (1985), o tempo de crescimento radicular a uma taxa linear é diretamente proporcional à concentração de boro disponível na solução nutritiva.
Considerando-se que esse micronutriente não se transloca facilmente de um órgão para outro, mostrando um transporte unidirecional via corrente transpiratória (Shelp et al., 1995), sabe-se que é necessário um suprimento contínuo de boro para manutenção da atividade meristemática (Gupta, 1993). Estas observações sugerem que, uma vez que o boro entre no córtex da raiz, deve ser rapidamente utilizado, antes de se tornar "não disponível" para as células em divisão, devido à sua rápida remoção pela corrente transpiratória.

Os primeiros sintomas da omissão de boro nas plantas de feijão, utilizadas nesse experimento, apareceram no ápice radicular, concordando com os resultados obtidos em raízes de Vicia faba $\mathrm{L}$. (Warington, 1923), tomate e girassol (Kouchi \& Kumazawa, 1975).

Yih \& Clark (1964) constataram que a omissão de boro, na solução nutritiva, inibiu o alongamento radicular, observando o aparecimento anormal de raízes laterais próximo ao ápice radicular de plantas de tomate. Confirmando esses resultados, no presente trabalho, ocorreu diferenciação de elementos traqueais e surgimento de primórdios radiculares próximo à região onde, nas raízes das plantas testemunha, era observado um grupo de células iniciais constituindo o promeristema.

$\mathrm{Na}$ Coleta II, os efeitos da omissão de boro se acentuaram com o ápice radicular tornando-se necrótico, ocorrendo o aparecimento de vários primórdios radiculares, à pouca distância do mesmo, à semelhança dos efeitos observados por Dugger (1983), em raízes de plantas de linho submetidas à omissão de boro.

De acordo com Howeler et al. (1978), plantas de feijão carentes de boro não completam o ciclo, reiterando que o boro não permite a viabilidade do feijoeiro em sua omissão. Os resultados obtidos nesse estudo vêm corroborar com essa afirmação, uma vez que apresentando alterações em processos como divisão, diferenciação e alongamento celular, o crescimento da raiz foi comprometido, provocando a morte das plantas ao $55^{\circ}$ dia após o transplante.

Todavia, existem controvérsias a respeito de qual seja o efeito primário da omissão de boro em raízes. Segundo Kouchi \& Kumazawa (1975), o efeito primário da omissão de boro em raízes de tomateiro e girassol, foi a cessação da divisão e do alongamento celular. No entanto, Cohen \& Lepper (1977) consideraram que a cessação do alongamento de raízes de abóbora, submetidas à omissão de boro, foi causada pela falta de divisão das células meristemáticas e não por falta de alongamento celular, sugerindo que esse micronutriente age como um regulador da divisão celular.

Verificam-se na literatura, descrições frequentes de atraso no desenvolvimento da raiz, em plantas submetidas à omissão de boro, devido a alterações na síntese de DNA e decréscimo no conteúdo de RNA, precedido de redução no conteúdo de proteína e aumento na atividade da RNAase (Chapman \& Jackson, 1974; Krueger et al., 1987). Sabe-se também que, sob condições 
de omissão de boro ou concentrações supra-ótimas de auxina, o alongamento radicular fica inibido (Coke \& Whittington, 1968), mas aparentemente não pelo mesmo mecanismo fisiológico (Hirsch \& Torrey, 1980).

$O$ fato de existirem somente evidências da participação do boro em reações enzimáticas e, apesar de comprovada a sua essencialidade em plantas, até hoje tudo o que se levanta são hipóteses a respeito do seu possível papel na planta (Lovatt, 1985; Gupta, 1993; Matoh, 1997).

\section{REFERÊNCIAS BIBLIOGRÁFICAS}

ALMEIDA, L. D'A.; LEITÃO FILHO, H.F.; MIYASAKA, S. Características do feijão Carioca, um novo cultivar. Bragantia, v.30, p. 33-38, 1971.

AMBROSANO, E.J.;WUTKE, E.B.; AMBROSANO, G.M.B.; BULISANI, E.A.; BORTOLETTO, N.; MARTINS, A.L.M.; PEREIRA, J.C.V.N.A.; SORDI, G. Efeito do nitrogênio no cultivo de feijão irrigado no inverno. Scientia Agricola, v.53, p.338-342, 1996.

CHAPMAN, K.S.R.; JACKSON, J.F. Increased RNA labelling in boron-deficient root tip segments. Phytochemistry, v.13, p.1311-1318, 1974.

COHEN, M.S.; LEPPER, R. Effects of boron on cell elongation and division in squash roots. Plant Physiology, v.59, p.884-887, 1977.

COKE, L.; WHITTINGTON, W.J. The role of boron in plant growth: IV. Interrelationships between boron and indol-3ylacetic acid in the metabolism of bean radicles. Journal of Experimental Botany, v.19, p.295-308, 1968.

DUGGER JR., W.M. Boron in plant metabolism. In: LAUCHLI, A.: BIELESKI, R.L. (Ed.) Plant physiology. New York: Springer-Verlag, 1983., p.626-650.

ESAU, K. Plant anatomy. New York: John Wiley, 1965. 767p. FAHN, A. Plant anatomy. Oxford: Pergamon Press, 1982. 544p.

GUPTA, U.C. Boron and its role in crop production. New York: CRC Press, 1993. 237p.

HIRSCH, A.M.; TORREY, J.G. Ultrastructural changes in sunflower root cells in relation to boron deficiency and added auxin. Canadian Journal of Botany, v.58, p.856-866, 1980.

HOAGLAND, D.R.; ARNON, D.I. The water culture method for growing plants without soil. Circular College Agricultural University California, v.347, p.1-32, 1950.

JOHANSEN, D. Plant microtechnique. New York: McGraw-Hill, 1940. 523p.

KOUCHI, H.; KUMAZAWA, K. Anatomical responses of root tips to boron deficiency: I. Effects of boron deficiency on elongation of root tips and their morphological characteristics. Soil Science of Plant Nutrition, v.21, p.21-28, 1975.

KRUEGER, R.W.; LOVATT, C.J.; ALBERT, L.S. Metabolic requirement of Cucurbita pepo for boron. Plant Physiology, v.83, p.254-258, 1987.

LEWIS, D.H. Boron, lignification and the origin of vascular plants - a unified hypothesis. New Phytologist, v.84, p.209-229, 1980.
LOVATT, C.J. Evolution of xilem resulted in a requirement for boron in the apical meristems of vascular plants. New Phytologist, v.99, p.509-522, 1985.

MALAVOLTA, E.; DAMIÃO FILHO, C.F.; VOLPE, C.A.; MACHADO JÚNIOR, G.R.; VELHO, L.M.S.; ROSA, P.R.F.; LAURENTIZ, S. Deficiências e excessos minerais no feijoeiro (Phaseolus vulgaris L. cv. Carioca). Anais da ESALQ, v.37, p.701-718, 1980a.

MALAVOLTA, E.; ULLOA, A.M.C.; MORALES, L.E.M.; ORTIZ, O.G.B.; CABALLERO, S.U.; ARAUJO, J.A.C.; MORAES, O.; SIMABUCO, S.M.; FREITAS, S.S.; FAQUIM, V.; NASCIMENTO, V.M.; RUY, V.M.; GALBIATTI, J.A.; LIMA, S.L.; ANGULO FILHO, R. Efeitos das deficiências de alguns micronutrientes em dois cultivares (Santa Rosa e UFV-1) de soja (Glycine max (L.) Merril). Anais da ESALQ, v.37, p.365-372, 1980b.

MARSCHNER, $H$. Mineral nutrition of higher plants. London: Academic Press, 1986. 671p.

MATOH, T. Boron in plant cell walls. Plant and Soil, v.193, p.1-13, 1997.

McILRATH, W.J.; PALSER, B.F. Responses of tomato, turnip, and cotton to variations in boron nutrition: I. Physiological responses. Botanical Gazette, v.118, p.43-52, 1956.

MIKSCHE, J.P. Developmental vegetative morphology of Glycine max. Agronomy Journal, v.53, p.121-128, 1961.

MORAES-DALLAQUA, M.A.; BELTRATI, C.M.; PEDRAS, J.F. Alterações morfológicas no caule de feijoeiro (Phaseolus vulgaris L. cv. Carioca) causadas por diferentes níveis de boro, na solução nutritiva. Revista de Agricultura, v.73, p.183-200, 1998.

PILBEAM, D.J.; KIRKBY, E.A. The physiological role of boron in plants. Journal of Plant Nutrition, v.6, p.363-382, 1983.

POMPEU, A.S. Melhoramento do feijoeiro (Phaseolus vulgaris L.). In: BULISANI, E.A. (Coord.) Feijão: fatores de produção e qualidade. Campinas: Fundação Cargill, 1987. p.1-28.

POPHAM, R.A. Levels of tissue differentiation in primary roots of Pisum sativum. American Journal of Botany, v.42, p.529-540, 1955.

SASS, J.E Botanical microtechnique. Ames: lowa State University Press, 1951. 228p.

SHELP, B.J.; MARENTES, E.; KITHEKA, A.M.; VIVEKANANDAN, P. Boron mobility in plants. Physiologia Plantarum, v.94, p.356-361, 1995.

SILVA, E.A.M. Desenvolvimento anatômico dos órgãos vegetativos do feijoeiro (Phaseolus vulgaris L.): II. Ápice Radicular. Revista Ceres, v.36, p.201-205, 1989.

VAN DE VENTER, H.A.; CURRIER, H.B. The effect of boron deficiency on callose formation and $14 \mathrm{C}$ translocation in bean (Phaseolus vulgaris L.) and cotton (Gossipium hirsutum L.). American Journal of Botany, v.64, p.861-865, 1977.

WARINGTON, K. The effect of boric acid and borax on the broad bean and certain other plants. Annals of Botany, v.37, p.629-672, 1923.

YIH, R.Y.; CLARK, H.E. Carbohydrate and protein content of boron-deficient tomato root tips in relation to anatomy and growth. Plant Physiology, v.40, p.312-315, 1964.

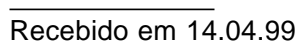

